

DOI : 10.15740/HAS/TAJAS/12.2/134-137

Visit us | www.researchjournal.co in

RESEARCH ARTICLE........

\title{
Diurnal reproductive behaviour of Indian flying fox, Pteropus giganteus
}

\author{
RAM KUMAR, DEEP NARAYAN PRASAD AND VADAMALAI ELANGOVAN

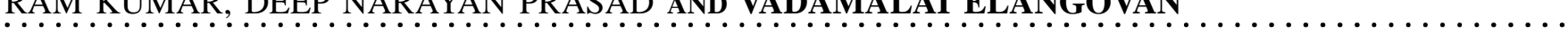

Author for Corresponding -

VADAMALAI ELANGOVAN Department of Applied Animal

Sciences, Babasaheb Bhimrao

Ambedkar University, LUCKNOW

(U.P.) INDIA

Email : elango70@yahoo.com

See end of the article for

Coopted authors'
ABSTRACT...... The reproductive behaviour of Indian flying fox, Pteropus giganteus was observed at a maternity colony situated in Ambedkar Nagar district of Uttar Pradesh, India. The behavioural activities of $P$. giganteusat pre- and post-copulation period was observed. The bats were actively involved in copulation form July to November, however the frequency of copulation was higher during September. Although, bats were engaged on reproductive activities over the day but intensive copulation was observed during the forenoon than afternoonhours. The bats chosen the peripheral and open canopies for copulation than leafy and dense area. The male individuals consistently courted the females by stretching their wings, licking vulva and producing vocal sounds. The observation on vulva licking showed a significant relationship with duration and frequency of copulation. Hence, the finding of this study may use substantially in further studies with reference to reproductive aspects of bats biology.

KEY WORDS...... Copulatory behaviour, Pteropus giganteus, Reproductive season, Roost site selection

HOW TO CITE THIS ARTICLE - Kumar, Ram, Prasad, Deep Narayan and Elangovan, Vadamalai (2017). Diurnal reproductive behaviour of Indian flying fox, Pteropus giganteus. Asian J. Animal Sci., 12(2): 134-137. DOI : 10.15740/HAS/TAJAS/12.2/134-137.

ARTICLE CHRONICLE - Received : 20.10.2017; Revised : 09.11.2017; Accepted : 22.11.2017 